\title{
Moringa oleifera attenuates biochemical and histological changes associated with the pancreas in nicotine-treated rats
}

\author{
*Omotoso G.O. ${ }^{1}$, Adunmo G.O. ${ }^{2}$, Ojulari L.S. ${ }^{3}$, Olawuyi T.S. ${ }^{4}$, Lewu F.S. ${ }^{1}$, \\ Jaji-Sulaimon R. ${ }^{1}$, Sulaimon F.A. ${ }^{1}$, Gbadamosi I.T. ${ }^{1}$, Onoja O.P. ${ }^{1}$
}

\begin{abstract}
Objective: The study was undertaken in order to evaluate the beneficial potential of Moringa oleifera, in nicotine-induced pancreatic injury.

Method: Forty-five adult female albino rats were divided into 5 groups A-E, each group having nine rats. Group A received normal saline; group B received $6.88 \mathrm{mg} / \mathrm{kg}$ of nicotine intraperitoneally (i.p); group C received $6.88 \mathrm{mg} / \mathrm{kg}$ of nicotine i.p. and $200 \mathrm{mg} / \mathrm{kg}$ of Moringa oleifera leaf powder dissolved in $2 \mathrm{ml}$ of normal saline (orally); group D received $13.76 \mathrm{mg} / \mathrm{kg}$ of nicotine i.p., while group E received $13.76 \mathrm{mg} / \mathrm{kg}$ of nicotine i.p. and $200 \mathrm{mg} / \mathrm{kg}$ of Moringa oleifera leaf powder dissolved in $2 \mathrm{ml}$ of normal saline (orally). Treatment was for 8 days and the rats were sacrificed after 24 hours of termination of study. Intracardial blood specimens were obtained to analyse blood glucose, while the pancreas was excised and either fixed in $4 \%$ paraformaldehyde for histology or sucrose solution and homogenised for biochemical analysis of lactate dehydrogenase (LDH) and glucose-6-phosphate dehydrogenase (G-6-PDH) enzymes.
\end{abstract}

Results: In comparison with the Control, animals treated with low dose of nicotine with or without Moringa oleifera and those treated with high dose of nicotine plus Moringa oleifera had reduction in body weights $(\mathrm{p}>0.05)$, while marked reduction in pancreatic weights was noted in low dose nicotine $(\mathrm{p}<0.05)$ and both nicotine groups co-treated with Moringa oleifera $(\mathrm{p}<0.05)$. There were no significant changes in the levels of blood glucose and pancreatic G-6-PDH levels, while significant reduction occurred in pancreatic LDH levels in nicotine-treated rats $(\mathrm{p}<0.05)$. However, LDH improved following coadministration with Moringa oleifera. Observation of the histology of the pancreas revealed atrophy of intercalated ducts, poorly delineated and disintegrating islet of Langerhans in animals treated with the higher dose of nicotine, while changes in pancreatic tissue in animals co-treated with Moringa oleifera were not as severe as the nicotine-treated animals.

Conclusion: Moringa oleifera leaf decoction minimally ameliorates morphological and biochemical changes associated with nicotine-induced pancreatic damage.

Keywords: Nicotine, Pancreatic damage, Moringa oleifera

\footnotetext{
*Correspondence author

Dr Omotoso G.O.

http://orcid.org/0000-0001-7727-6943

Email: omotoso.go@unilorin.edu.ng,gabrielolaiya@yahoo.com

${ }^{1}$ Department of Anatomy, Faculty of Basic Medical Sciences, University of Ilorin, Ilorin, Nigeria.

${ }^{2}$ Department of Medical Biochemistry, Faculty of Basic Medical Sciences, University of Ilorin, Ilorin, Nigeria.

${ }^{3}$ Department of Physiology, Faculty of Basic Medical Sciences, University of Ilorin, Ilorin, Nigeria.

${ }^{4}$ Department of Anatomy, Federal University of Technology, Akure. Nigeria.
} 


\title{
Moringa oleifera atténue les modifications biochimiques et histologiques associées au pancréas chez les rats traités à la nicotine
}

\author{
*Omotoso G.O. ${ }^{1}$, Adunmo G.O. ${ }^{2}$, Ojulari L.S. ${ }^{3}$, Olawuyi T.S. ${ }^{4}$, Lewu F.S. ${ }^{1}$, \\ Jaji-Sulaimon R. ${ }^{1}$, Sulaimon F.A. ${ }^{1}$, Gbadamosi I.T. ${ }^{1}$, Onoja O.P. ${ }^{1}$
}

\begin{abstract}
Abstrait
Objectif: L'étude visait à évaluer le potentiel bénéfique de Moringa oleifera, dans le traitement des lésions pancréatiques induites par la nicotine.

Méthode: Quarante-cinq rats albinos femelles adultes ont été divisés en 5 groupes Aà E, chaque groupe comportant neuf rats. Le groupe A a reçu une solution saline normale; le groupe B a reçu $6,88 \mathrm{mg} / \mathrm{kg}$ de nicotine par voie intraperitoneale (i.p); le groupe C a reçu $6,88 \mathrm{mg} / \mathrm{kg}$ de nicotine i.p. et $200 \mathrm{mg} / \mathrm{kg}$ de poudre de feuilles de Moringa oleifera en solution dans $2 \mathrm{ml}$ de solution saline normale (par voie orale); le groupe D a reçu $13,76 \mathrm{mg} / \mathrm{kg}$ de nicotine par voie intraveineuse, tandis que le groupe E a reçu $13,76 \mathrm{mg} / \mathrm{kg}$ de nicotine par voie intraveineuse. et $200 \mathrm{mg} / \mathrm{kg}$ de poudre de feuilles de Moringa oleifera en solution dans $2 \mathrm{ml}$ de solution saline normale (par voie orale). Le traitement a duré 8 jours et les rats ont été sacrifiés 24 heures après la fin de l'étude. Des échantillons de sang intracardiques ont été obtenus pour analyser la glycémie, tandis que le pancréas était excisé et fixé dans du paraformaldéhyde à $4 \%$ pour l'histologie ou dans une solution de saccharose et homogénéisé pour l'analyse biochimique de la lactate déshydrogénase (LDH) et de la glucose-6-phosphate déshydrogénase (G-6- PDH) enzymes.
\end{abstract}

Résultats: Comparativement au témoin, les animaux traités avec une faible dose de nicotine avec ou sans Moringa oleifera et ceux traités avec une forte dose de nicotine plus Moringa oleifera présentaient une réduction du poids corporel $(\mathrm{p}>0,05)$, tandis qu'une réduction marquée du poids pancréatique était notée. nicotine à faible dose ( $\mathrm{p}$ $<0,05)$ et les deux groupes de nicotine co-traités avec Moringa oleifera $(\mathrm{p}<0,05)$. Il n'y a pas eu de changements significatifs dans les taux de glucose sanguin et les taux de G-6-PDH dans le pancréas, tandis qu'une réduction significative est survenue dans les taux de LDH dans le pancréas chez les rats traités à la nicotine $(p<0,05)$. Cependant, la LDH s'est améliorée après la co-administration de Moringa oleifera. L'observation de l'histologie du pancréas a révélé une atrophie des canaux intercalés, des îlots de Langerhans mal délimités et désagrégés chez les animaux traités avec la plus forte dose de nicotine, tandis que les modifications du tissu pancréatique chez les animaux co-traités avec Moringa oleifera n’étaient pas aussi sévères que la nicotine. animaux traités.

Conclusion: La décoction de feuilles de Moringa oleifera atténue peu les modifications morphologiques et biochimiques associées aux dommages pancréatiques induits par la nicotine.

Mots-clés: Nicotine, dommage pancréatique, Moringa oleifera

\footnotetext{
* Auteur de la correspondance

Dr Omotoso G.O.

http://orcid.org/0000-0001-7727-6943

Email: omotoso.go@unilorin.edu.ng,gabrielolaiya@yahoo.com

${ }^{1}$ Department of Anatomy, Faculty of Basic Medical Sciences, University of Ilorin, Ilorin, Nigeria.

${ }^{2}$ Department of Medical Biochemistry, Faculty of Basic Medical Sciences, University of Ilorin, Ilorin, Nigeria.

${ }^{3}$ Department of Physiology, Faculty of Basic Medical Sciences, University of Ilorin, Ilorin, Nigeria.

${ }^{4}$ Department of Anatomy, Federal University of Technology, Akure. Nigeria.
}

Research Journal of Health Sciences subscribed to terms and conditions of Open Access publication. Articles are distributed under the terms of Creative Commons Licence (CC BY-NC-ND 4.0). (http://creativecommons.org/licences/by-nc-nd/4.0)

http://dx.doi.org/10.4314/rejhs.v6i4.3 


\section{INTRODUCTION}

Despite public enlightenment and various health initiatives, tobacco addiction is still a major health challenge in both developed and developing countries (1). Among females, the rate of tobacco smoking is actually high, and in the female subgroup, the number of smoking mothers is steadily increasing (2). Nicotine is the major additive component of tobacco cigarette and although tobacco use has severe health implications, one third of the world's population still use tobacco products (3). Nicotine is an alkaloid tertiary amine composed of a pyridine and pyrolidine ring (4), consisting of two stereo isomeric isomers $(\mathrm{S})$-nicotine and $(\mathrm{R})$-nicotine. Out of these two, (S)-nicotine is more active, contributing $90 \%$ of the pharmacologically active nicotine found in tobacco (5).

Nicotine contributes to the development of many clinical conditions including pancreatic pathologies (6-8). A study by Chowdhury et al (9) showed that administration of nicotine to rodents induced morphologic pancreatic alterations, and the mechanism by which nicotine relays its effects was suggested to be mediated by nicotinic acetylcholine receptors (10). Juvenile Wistar rats exposed to nicotine during gestation showed apoptosis of pancreatic beta cells and abnormal glucose tolerance (11), with reduced beta cells mass from birth up to adulthood (12). Invariably, this portends complete loss of beta cell composition, thus resulting in increased glucose level which poses a considerable risk on structural and functional development. All these point to reduced functionality of the pancreas and dysfunctional carbohydrate metabolism. Exposure to nicotine alters pancreatic islets gene expression of different transcription factors specific for endocrine cells (Pdx-1, Pax-6, and Nkx6.1) and hormones, such as insulin and glucagon (12). Because of these altered physiological parameters, the normal physiological control of glucose homeostasis is also altered considerably (13).

The medicinal and therapeutic significance of Moringa oleifera has been lauded over the last few decades. It is the most widely cultivated species of Moringaceae (14). There has been much discourse on the health and nutritional benefits of Moringa oleifera, including the leaves, flowers, seeds, seed oil, stem bark and roots of the plant $(15,16)$. Its usefulness ranges from its consumption as a nutritional supplement to its use in the management of many clinical conditions as a result of its reported antimicrobial, antioxidative, antiulcer, cytoprotective, cardiovascular, antidiabetic, anticancer and neuroprotective properties (14, 17-22). Phytochemical components of Moringa include compounds such as 4 -(4'- $O$-acetyl- $\alpha$-L-rhamnopyranosyloxy) benzyl isothiocyanate, 4-benzyl isothiocyanate, pterygospermin, benzyl isothiocyanate, and 4benzyl glucosinolate $(23,24)$. In addition, the Moringa oleifera leaves also contain tannins, steroids, triterpenoids, flavonoids, saponins, anthraquinones, alkaloids, niazimicin and moringin (25). Some of these constituents have clinical relevance.

This research work was aimed at determining if administration of Moringa oleifera leaf powder has protective effect on the pancreas and carbohydrate metabolism of Wistar rats following nicotine exposure.

\section{MATERIALS AND METHODS Ethical Approval}

Approval was obtained from the Ethical Review Committee of the Faculty of Basic Medical Sciences, University of Ilorin and the study was carried out in line with the rules and guidelines set by the committee.

\section{Experimental Animals}

Forty five (45) female albino rats (5-6 weeks old) were used and the study was conducted in the Animal Facility of the Faculty of Basic Medical Sciences, University of Ilorin. They had free access to pelletised growers' feed containing $15 \%$ crude protein, $7 \%$ Fat, $10 \%$ crude fibre, $1 \%$ calcium, $0.35 \%$ phosphorus, 2,550 $\mathrm{kcal} / \mathrm{kg}$ of metabolised energy and clean water within a hygienic environment. The weights of the animals were recorded on the first day of acclimatization and on specific days during the course of the experiment.

\section{Procurement of Nicotine and Preparation of Moringa oleifera}

Nicotine (95\%; British Drug House ${ }^{\circledR}$, Poole, England) was titrated to arrive at a dose of $13.76 \mathrm{mg} / \mathrm{kg}$ in $0.1 \mathrm{ml}$ vehicle, which was the maximum tolerable dose by the rats, though less than the $\mathrm{LD}_{50}$ of intraperitoneal nicotine (14.6 $\mathrm{mg} / \mathrm{kg}$ ) (26). Two doses of nicotine were prepared: one, half of the titrated dose (6.88 $\mathrm{mg} / \mathrm{kg})$ and two, the titrated dose $(13.76 \mathrm{mg} / \mathrm{kg})$. Commercially produced Moringa oleifera leaf powder was procured from a herbal store near the University mini campus, Ilorin. A dose of 200 $\mathrm{mg} / \mathrm{kg}$ (24) was prepared and dissolved in $2 \mathrm{ml}$ of normal saline. 


\section{Study Design and Drug Administration}

The animals were randomly grouped into five classes, with each class having nine rats as follows:

- Group A (control): received $0.1 \mathrm{ml}$ of normal saline intraperitoneally (i.p.);

- Group B: were given $6.88 \mathrm{mg} / \mathrm{kg}$ nicotine (i.p.);

- Group C: received $6.88 \mathrm{mg} / \mathrm{kg}$ nicotine (i.p.) and $200 \mathrm{mg} / \mathrm{kg}$ of Moringa oleifera (oral);

- Group D: received $13.76 \mathrm{mg} / \mathrm{kg}$ nicotine (i.p.);

- Group E: received $13.76 \mathrm{mg} / \mathrm{kg}$ nicotine (i.p.) and $200 \mathrm{mg} / \mathrm{kg}$ of Moringa oleifera (oral).

Moringa oleifera was administered about 15 minutes prior to the administration of nicotine and treatments lasted for 8 consecutive days.

\section{Animal Sacrifice and Specimen Collection}

After the last day of administration, the animals were fasted overnight and their weights were recorded. Animals for histological studies were administered with intramuscular ketamine $(0.1 \mathrm{ml})$ prior to sacrifice, and abdominal incision was made to expose and excise the pancreas. The pancreatic tissue was thereafter weighed and placed in $4 \%$ buffered paraformaldehyde (PFA) as fixative for histology. Other animals were sacrificed by cervical dislocation to avoid interference of the anaesthetic agent (ketamine) with the biochemical parameters to be investigated. The thorax was accessed to identify the heart for intracardial withdrawal of blood sample from the left ventricle and dispensed into appropriate sample bottles. The pancreas of the rats sacrificed by cervical dislocation was placed in separate sample bottles for biochemical studies.

\section{Biochemical Studies}

The blood sample obtained was centrifuged and the supernatant scooped into a separate bottle for determination of plasma glucose level. Glucose levels in plasma were determined using the technique described by Trinder (27) and Cheesebrough (28). Part of the pancreas was homogenized in $1 \mathrm{ml} 0.25 \mathrm{M}$ sucrose solution using a homogenizer. The homogenates were centrifuged and the supernatants were used for enzymatic assessment of lactate dehydrogenase (LDH) and glucose-6phosphate dehydrogenase (G-6-PDH) as previously described $(29,30)$.

\section{Tissue Processing for Light Microscopy}

The PFA-fixed pancreas was processed by subjecting it to the processes of clearing, dehydration and embedding. The resulting paraffin blocks were sectioned using a microtome and stained using Haematoxylin and Eosin stains (31).

\section{Statistical Analysis}

Data were analysed using ANOVA, followed by Tukey's multiple comparison tests with the aid of SPSS version 20 and presented as mean and standard error of mean. P values less than 0.05 were considered statistically significant.

\section{RESULTS}

\section{Morphological Observation}

The body weights varied across the groups. There was weight increase in rats in the control, while the other treated animals had reduction in their body weights at termination of study $(p>0.05)$. Animals treated with low dose of nicotine had a minimal weight reduction (Group B), while those treated with high dose of nicotine (Group D) had negligible weight change $(p>0.05)$. Meanwhile, the rats co-administered with nicotine and Moringa oleifera (Groups C and E) had more marked weight difference; however, these changes were not statistically significant ( $p>0.05)$ (Figure 1).

There were highly statistically significant differences in the weights of the pancreas in the treated Wistar rats $(\mathrm{p}<0.05)$. Animals coadministered with nicotine (irrespective of dose) and Moringa oleifera (Groups C and E) had markedly reduced organ weight, as well as animals treated with low dose of nicotine only $($ Group B) $(p<0.05)$ (Figure 2).

\section{Biochemical Observations}

i. Blood Glucose Level

Minimal reduction in plasma glucose levels were noticed across the groups when compared with the Control. Animals treated with the low dose of nicotine (Group B) had a lower glucose level compared with the Control and the high dose nicotine group (Group D), while animals coadministered with Moringa oleifera and high dose of nicotine (Group E) had the least glucose level, when compared with all the other groups. These changes however were not statistically significant $(\mathrm{p}>0.05)($ Table 1$)$.

\section{ii. Lactate Dehydrogenase (LDH)}

Nicotine treatment led to significant reduction in the lactate dehydrogenase levels in pancreatic 
tissue, with animals exposed to the low dose of nicotine (Group B) having the lowest level compared to other groups. The difference in $\mathrm{LDH}$ levels between the high dose nicotine group (D) and the low dose nicotine group (B) was statistically significant $(p<0.05)$, while the elevated LDH levels observed in rats administered with Moringa oleifera alongside nicotine (Groups C and E) were not significant when compared with the Control $(p>0.05)$, but significant when compared with the low dose group (B) $(\mathrm{p}<0.05)($ Table 1$)$.

\section{iii. Glucose-6-phosphate Dehydrogenase (G-6-PDH)}

The levels of G-6-PDH were reduced in all the treated groups when compared with the Control $(\mathrm{p}>0.05)$. Nicotine-treated rats had no significant change in G-6-PDH levels irrespective of the dose administered; however, rats exposed to the high dose of nicotine and Moringa oleifera had the lowest level of G-6-PDH, although this difference was not statistically significant $(\mathrm{p}>0.05)$ (Table 1).

\section{Histological Observations}

Observation of the pancreas of the control animals showed pancreatic architecture with well delineated pancreatic islet of Langerhans. There were marked differences in the cellular architecture of the pancreas from nicotine-treated groups compared with the Control. In nicotine treatment groups, there was marked atrophy of pancreatic intercalated ducts, as well as few exocrine glands. Pancreatic islets of Langerhans revealed little or no histological changes in animals that received the low dose of nicotine, while those that received a higher dose showed degenerative changes when compared to the control (Figure 3).

\section{DISCUSSION}

Exposure to nicotine, either through direct cigarette smoking or second-hand smoke has negative effects on body structures and functions. Earlier studies have revealed that nicotine consumption is usually associated with reduction in body weight, as it increases energy expenditure and reduces appetite $(32,33)$. From the current study, the effect of nicotine on body weight was such that the lower dose caused slight weight loss but a higher dose showed no apparent negative weight change. The reason for the mild weight changes might be due to the short duration of nicotine administration (eight days).

The observation of the absence of weight loss in animals given high dose nicotine appears to be in line with a study by Bamia et al (34) which revealed that among smokers, heavy smokers tend to have increase in body weights compared to light smokers. Although we did not report an increase in body weight in this group of animals, it might just be a process that is ongoing, considering the short period of nicotine treatment.

Nicotine consumption impairs glucose tolerance and insulin sensitivity and is a risk factor for many cardiovascular and metabolic clinical conditions $(35,36)$. In human, epidemiological studies have demonstrated a relationship between high serum glucose and increased prevalence of diabetes in individuals exposed to varying concentrations of nicotine (37). Hyperglycaemia occurring after nicotine treatment or cigarette smoking has been suggested to be partly hormonal, as this involves mobilization of catecholamines and cortisol production (38). Bruin et al (39) showed that Wistar rats exposed to nicotine during foetal and neonatal life presented with increased beta-cell apoptosis at birth. This could be responsible for the reduced pancreatic weight and altered architecture of the pancreas observed in this study.

Nicotine is an oily liquid and watersoluble substance that is easily absorbed into the bloodstream and it penetrates readily the body tissues. There is conclusive evidence of its cytotoxic and deleterious effects on cell growth (40); however parallel studies have also shown that nicotine could prolong survival of certain cells, such as neutrophils and smooth muscle cells (41).

Numerous studies have examined and explored the hypoglycaemic properties of Moringa oleifera (42-45). In the current study, administration of nicotine with or without Moringa oleifera led to slight reduction in blood glucose levels. The reason for the non-significant reduction in glucose levels might be as a result of the short-term exposure to nicotine as designed by this study. Furthermore, nicotine administration caused a dose-dependent effect on sugar level, with animals treated with a lower dose having the lower glucose level. However, the high dose nicotine group co-administered with Moringa recorded the least sugar level. Notwithstanding these findings, the occurrence of a lower blood glucose level in animals exposed simultaneously to a high dose of nicotine and Moringa compared to others given a high dose of nicotine only is more representative of the effect 
of Moringa in nicotine-associated hyperglycaemia.

Assessment of pancreatic tissue lactate dehydrogenase (LDH) showed that nicotine administration caused a reduced enzyme activity, as significant reduction occurred in LDH level of animals exposed to the lower dose of nicotine. Co-administration with Moringa oleifera, irrespective of nicotine dose, led to elevated levels of pancreatic LDH, even higher than the Control level. Hence, there is the likelihood of Moringa oleifera acting to enhance the normal activity of lactate dehydrogenase in the pancreas. The reduced level of pancreatic LDH activity in rats exposed to nicotine suggests $\mathrm{LDH}$ enzyme leakage into the circulation due to possible pancreatic necrosis caused by nicotine, resulting in possible elevated serum LDH level, although serum LDH was not assessed in this study. However, this process is similar to what obtains in other forms of cytotoxicity (46).

Glucose-6-phosphate dehydrogenase (G-6-PDH) is a cytosolic enzyme that plays a critical role in protection against reactive oxygen species (47). As noted by Gumustekin et al. (48), nicotine adversely affects the activity of G-6$\mathrm{PDH}$ in rat tissues and organs, similar to current findings, where nicotine administration at both low and high doses resulted in decrease in the levels of G-6-PDH with no substantial difference between the two nicotine groups. Concurrent administration of Moringa oleifera with nicotine only minimally increased G-6-PDH level in the low dose group, while it reduced G-6-PDH level at high dose of nicotine. This partly suggests that where there is nicotine-induced depletion or inactivity of G-6-PDH at a low dose, administration of Moringa oleifera could improve the activity of the enzyme.

Microscopic observations of nicotinetreated rats showed disruptions in pancreatic cytoarchitecture. This is reminiscent of the fact that nicotine administered in both low and high doses negatively affects pancreatic microarchitecture, and possibly the expected functions of various cells could be impaired. On the effect on pancreatic islets of Langerhans, exposure to a high dose of nicotine would more likely cause severe architectural damage and this could affect the endocrine function of the gland. Due to the reported therapeutic potential of Moringa oleifera against pancreatic pathology, the leaf component of the plant was administered to assess its role in ameliorating nicotine-induced pancreatic damage. The current work observed only minimal effect in restoring the architectural alterations that characterized nicotine-associated injury to the pancreas. Meanwhile, the anticancer properties of Moringa have been reported (49), and according to Berkovich et al. (50), the growth of cancer cells in the pancreas are inhibited by the leaf extract of the plant. However, the minimal effects seen in our study could be as a result of the shortness of the duration of Moringa administration.

\section{CONCLUSION}

Nicotine exposure is toxic to the pancreatic structure and functions, and these could be minimized by the use of Moringa leaf. Meanwhile, when used over a longer duration, Moringa leaf could probably play a more beneficial role in addressing nicotine-induced pancreatic pathology.

Acknowledgement: The authors acknowledged the assistance of technical staff members of the Department of Anatomy, University of Ilorin.

Conflict of interest: The authors declare, no conflict of interest regarding this paper.

\section{REFERENCES}

1. Benowitz NL. Nicotine addiction. N Engl J Med, 2010; 362:2295-2303.

2. Lombardi EMS, Prado GF, Santos UP, Fernandes FLA. Women and smoking: risks, impacts, and challenges. J. Bras. Pneumol. 2011; 37(1):118128.

3. Mackay J, Eriksen M. The tobacco atlas. Geneva: World Health Organization, 2002.

4. Gamieldien K, Maritz GS. Postnatal expression of cytochrome P450 1A1, 2A3 and 2B1 in neonatal rat lung: influence of maternal nicotine exposure. Exp Lung Res 2004; 30:121-133

5. Pool WF, Godin CS, Crooks PA. Nicotine racemization during nicotine smoking. The Toxicologist 1985; 5:232.

6. Imoto M, DiMagno EP. Cigarette smoking increases the risk of pancreatic calcification in late-onset but not early-onset idiopathic chronic pancreatitis. Pancreas. 2000; 21:115-119.

7. Morton C, Klatsky AL, Udaltsova N. Smoking, coffee, and pancreatitis. Am J Gastroenterol. 2004; 99:731-738.

8. Edderkaoui M, Thrower E. Smoking and pancreatic disease. J Cancer Ther 2013; 4(10A):34-40.

9. Chowdhury P, Rayford PL. Smoking and pancreatic disorders. Eur J Gastroenterol. Hepatol. 2000; 12:869-877.

10. van Westerloo DJ, Giebelen IA, Florquin S, Bruno MJ, Larosa GJ, Ulloa L. et al. The vagus nerve and nicotinic receptors modulate experimental pancreatitis severity in mice. 
Gastroenterology. 2006; 130(6):1822-30.

11. Bruin JE, Kellenberger, LD, Gerstein HC, Morrison KM, Holloway AC. Foetal and neonatal nicotine exposure and postnatal glucose homeostasis: identifying critical windows of exposure. J Endocrinol. 2007; 194:171-178.

12. Somm E, Schwitzgebel V, Vauthay D, Camm E, Chen C, Giacobino J. et al. Prenatal nicotine exposure alters early pancreatic islet and adipose tissue development with consequences and the control of body weight and glucose metabolism later in life. Endocrinology 2008; 149: 6289-99.

13. Somm E, Schwitzgebel V, Vauthay D, Aubert M, Huppi P. Prenatal nicotine exposure and the programming of metabolic and cardiovascular disorders. Mol. Cell. Endocrinol. 2009; 304:69-77.

14. Fahey JW. Moringa oleifera: A Review of the Medical Evidence for Its Nutritional, Therapeutic, and Prophylactic Properties. Part 1. Tree of life Journal.2005;1:5. URL: http://www.tfljournal.org/article.php/200512011 24931586. Accessed on 15/10/2016.

15. Promkum C, Kupradinun P, Tuntipopipat S, Butryee C. Nutritive evaluation and effect of Moringa oleifera pod on clastogenic potential in the mouse. Asian Pac. J. Cancer Prev. 2010; 11(3):627-632

16. Tsaknis J, Lalas S, Gergis V, Dourtoglou V, Spiliotis V. Characterization of Moringa oleifera variety Mbololo seed oil of Kenya. J Agric Food Chem. 1999; 47(11):4495-9.

17. Rao AV, Devi PU, Kamath $\mathrm{R}$. In vivo radioprotective effect of Moringa oleifera leaves. Indian Journal of Experimental Biology 2001;39:858-63

18. Hamza AA. Ameliorative effects of Moringa oleifera Lam seed extract on liver fibrosis in rats. Food Chem Toxicol.2010; 48(1):345-55.

19. Sathya TN, Aadarsh P, Deepa V, Murthy PB. Moringa oleifera Lam. leaves prevent cyclophosphamide-induced micronucleus and DNA damage in mice. International Journal of Phytomedicine 2010; 2(2): 147-154.

20. Sreelatha S, Jeyachitra A, Padma PR. Antiproliferation and induction of apoptosis by Moringa oleifera leaf extract on human cancer cells. Food Chem Toxicol. 2011;49:1270-1275.

21. Sharma V, Paliwal R. Chemo Protective role of Moringa oleifera and its isolated Saponin against DMBA induced Tissue Damage in male mice: A Histopathological analysis. Int. J. Drug Dev. \& Res. 2012; 4(4): 215-228.

22. Omotoso GO, Gbadamosi IT, Afolabi TT, Abdulwahab AB, Akinlolu AA. Ameliorative effects of Moringa on cuprizone-induced memory decline in rat model of multiple sclerosis. Anat Cell Biol. 2018; 51:119-127.

23. Saini RK, Sivanesan I, Keum Y-S. Phytochemicals of Moringa oleifera: a review of their nutritional, therapeutic and industrial significance. 3 Biotech. 2016;6(2):203. doi:10.1007/s13205-016-0526-3

24. Omotoso GO, Gbadamosi IT, Olajide OJ, DadaHabeeb SO, Arogundade TT, Yawson EO. Moringa oleifera phytochemicals protect the brain against experimental nicotine-induced neurobehavioural disturbances and cerebellar degeneration. Pathophysiology, 2018; 25: 57-62.

25. Nweze NO, Nwafor FI. Phytochemical, proximate and mineral composition of leaf extracts of Moringa oleifera Lam. from Nsukka, South-Eastern Nigeria. J. Pharm. Biol. Sci. 2014; 9:99-103.

26. Brčić KI. Facts about nicotine toxicity. Arh Hig Rada Toksikol (Archives of Industrial Hygiene and Toxicology) 2005; 56:363-371.

27. Trinder P. Determination of glucose in blood using glucose oxidase with an alternative oxygen acceptor. Ann. Clin. Biochem. 1969; 6:24-27.

28. Cheesebrough M. District Laboratory practice in tropical countries Part 1. Cambridge: Cambridge University Press, 2005.

29. Weisshaar D, Gossrau E, Faderl B. Normal ranges of alpha-HBDH, LDH, AP, and LAP as measured with substrate-optimated test charges. Med Welt. 1975; 26(9):387-92.

30. Lohr GW, Waller HD. Glucose-6-phosphate dehydrogenase methods of enzymatic analysis, 3rd Ed., Wehnheim: Varlag Chemie, 1974.

31. Pearse EAG. Histochemistry: Theoretical and Applied, $4^{\text {th }}$ ed. Vol. 1 and 2. Edinburgh, Churchill Livingstone. 1980.

32. John U, Hanke M, Rumpf H-J, Thyrian JR. Smoking status, cigarettes per day, and their relationship to overweight and obesity among former and current smokers in a national adult general population sample. Int J Obes 2005; 29:1289-1294.

33. Chiolero A, Faeh D, Paccaud F, Cornuz J . Consequences of smoking for body weight, body fat distribution, and insulin resistance. The American Journal of Clinical Nutrition, 2008; 87(4): 801-809

34. Bamia C, Trichopoulou A, Lenas D, Trichopoulos D. Tobacco smoking in relation to body fat mass and distribution in a general population sample. Int J Obes Relat Metab Disord. 2004; 28(8):10916.

35. Frati AC, Iniestra F, Ariza CR. Acute effect of cigarette smoking on glucose tolerance and other cardiovascular risk factors. Diabetes Care 1996; 19(2): 112-118.

36. Bajaj M. Nicotine and insulin resistance: when the smoke clears. Diabetes 2012; 61(12): 30783080 .

37. Huang RC, Burke V, Newnham JP, Stanley FJ, Kendall JE, Landau LI et al. Perinatal and childhood origins of cardiovascular disease. Int $\mathrm{J}$ Obes 2007; 31:236-244.

38. Bornemisza P, Suciu I. Effect of cigarette smoking on the blood glucose level in normals and diabetics. Med Interne. 1980; 18(4):353-6.

39. Bruin JE, Gerstein HC, Morrison KM, Holloway 
AC. Increased pancreatic beta-cell apoptosis following fetal and neonatal exposure to nicotine is mediated via the mitochondria. Toxicol Sci. 2008; 103:362-70.

40. Zimmerman M, McGeachie J. The effect of nicotine on aortic endothelium: A comparative study. Atherosclerosis 1987; 63:33-41.

41. Aoshiba K, Nagai A, Ysui S, Konno K. Nicotine prolongs neutrophil survival by suppression of apoptosis. J Lab Clin Med.1996; 127:186-194.

42. Bais S, Singh GS, Sharma R. Antiobesity and hypolipidemic activity of Moringa oleifera leaves against high fat diet-induced obesity in rats. Advances in Biology, 2014; Article ID 162914. https://doi.org/10.1155/2014/162914.

43. Ezeigbo O R, Barrah CS, Ezeigbo IC. Phytochemical analysis and antidiabetic effect of aqueous and ethanolic extracts of Moringa oleifera leaves in alloxan-induced diabetic Wistar albino rats using insulin as reference drug. International Journal of Diabetes Research, 2016; 5(3): 48-53

44. Khan W, Parveen R, Chester K, Parveen S, Ahmad S. Hypoglycemic potential of aqueous extract of Moringa oleifera leaf and in vivo GCMS metabolomics. Frontiers in Pharmacology. 2017;8:577. doi:10.3389/fphar.2017.00577.

45. Villarruel-López A, López-de la Mora DA, Vázquez-Paulino OD, Puebla-Mora AG, TorresVitela MR, Guerrero-Quiroz LA et al. Effect of Moringa oleifera consumption on diabetic rats.
BMC Complement Altern Med. (2018) 18:127. https://doi.org/10.1186/s12906-018-2180-2

46. Panda S. Butanolic fraction of Moringa oleifera Lam. (Moringaceae) attenuates isoprotrenolinduced cardiac necrosis and oxidative stress in rats: an EPR study. EXCLI Journal. 2015;14:6474.

47. Pinna A, Contini EL, Carru C, Solinas G. Glucose-6-phosphate dehydrogenase deficiency and diabetes Mellitus with severe retinal complications in a Sardinian population, Italy. Int J Med Sci. 2013; 10(13): 1907-1913.

48. Gumustekin K, Ciftci M, Coban A, Altikat S, Aktas O, Gul M et al. Effects of nicotine and vitamin E on glucose 6-phosphate dehydrogenase activity in some rat tissues in vivo and in vitro. J Enzyme Inhib Med Chem. 2005; 20(5):497-502.

49. Al-Asmari AK, Albalawi SM, Athar MT, Khan AQ, Al-Shahrani H, Islam M. Moringa oleifera as an anti-cancer agent against breast and colorectal cancer cell lines. PLoS One 2015; $10(8)$ : $\quad$ e 0135814 . d o i : 10.1371/journal.pone.0135814.

50. Berkovich L, Earon G, Ron I, Rimmon A, Vexler A, Lev-Ari S. Moringa oleifera aqueous leaf extract down-regulates nuclear factor-kappaB and increases cytotoxic effect of chemotherapy in pancreatic cancer cells. BMC Complement Altern Med. 2013;13:212. 
Table 1: Table showing blood glucose levels, and pancreatic lactate dehydrogenase (LDH) and glucose-6-phosphate dehydrogenase (G-6-PDH) activities

\begin{tabular}{llll}
\hline Groups & $\begin{array}{l}\text { Blood } \\
\text { Glucose } \\
(\mathrm{mmol} / \mathrm{L})\end{array}$ & LDH (IU/L) & $\begin{array}{l}\text { G-6-PDH } \\
(\mathrm{IU} / \mathrm{L})\end{array}$ \\
\hline A: Control & $4.40 \pm 0.17$ & $1743 \pm 41.81$ & $1293 \pm 15.72$ \\
$\mathrm{~B}: \mathrm{LDN}$ & $3.70 \pm 0.25$ & $1419 \pm 28.42 *$ & $1250 \pm 33.59$ \\
$\mathrm{C}: \mathrm{LDN}+\mathrm{M}$ & $4.17 \pm 0.59$ & $1859 \pm 40.43 \dagger$ & $1253 \pm 34.84$ \\
$\mathrm{D}: \mathrm{HDN}$ & $4.17 \pm 0.26$ & $1646 \pm 36.67 \dagger$ & $1249 \pm 32.44$ \\
E: HDN + M & $3.60 \pm 0.70$ & $1881 \pm 22.39 \dagger$ & $1225 \pm 2.91$ \\
\hline
\end{tabular}

$*(p<0.05)$ statistical significant difference compared to control group; $\dagger(\mathrm{p}<0.05)$ statistical significant difference compared to animals exposed to low dose nicotine (Group B).

LDN: low dose nicotine,

HDN: high dose nicotine, M: Moringa.

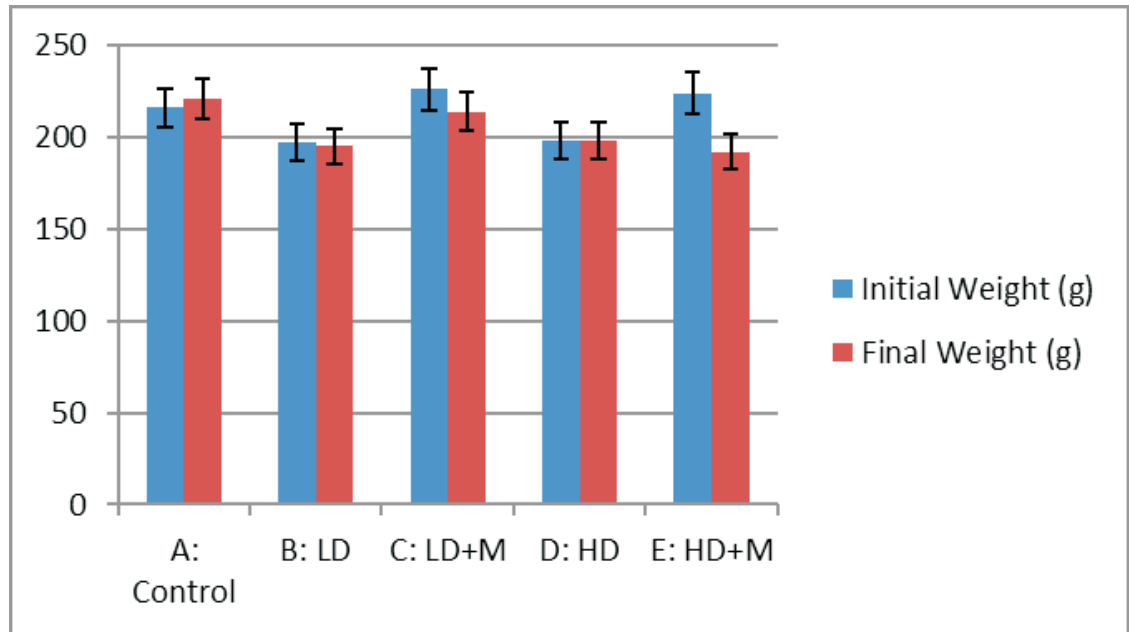

Figure 1: Weight changes in Experimental Animals.

$\mathrm{N}$ : nicotine,

LD: low dose nicotine,

HD: high dose nicotine,

M: Moringa. 


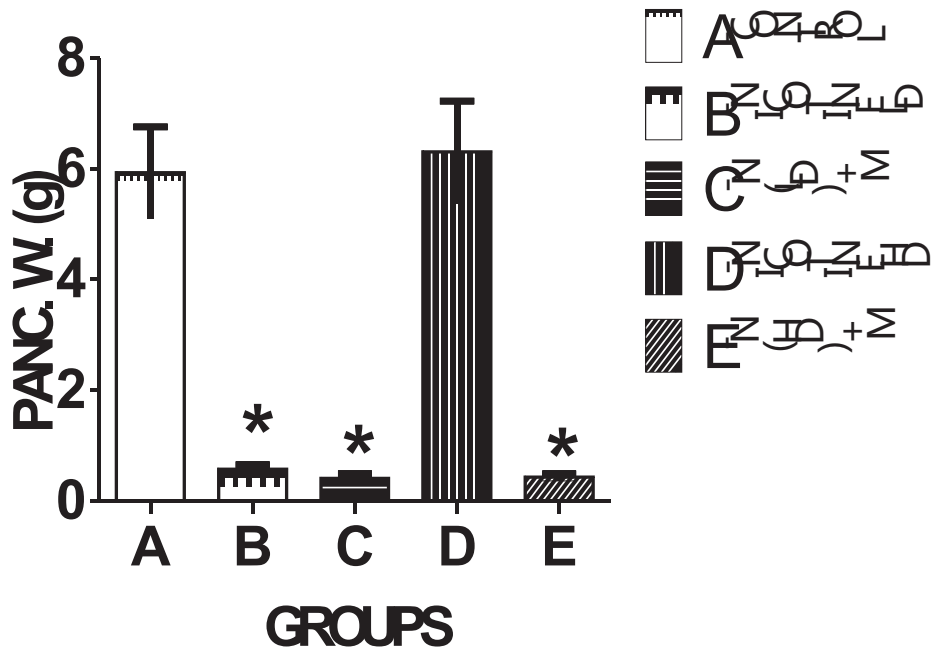

Figure 2: Weights of Pancreas in Experimental Animals. Reduction in pancreatic weight was significant in Groups $B, C$ and $E(P<0.05)$.

$\mathrm{N}$ : nicotine,

LD: low dose nicotine,

HD: high dose nicotine,

M: Moringa.
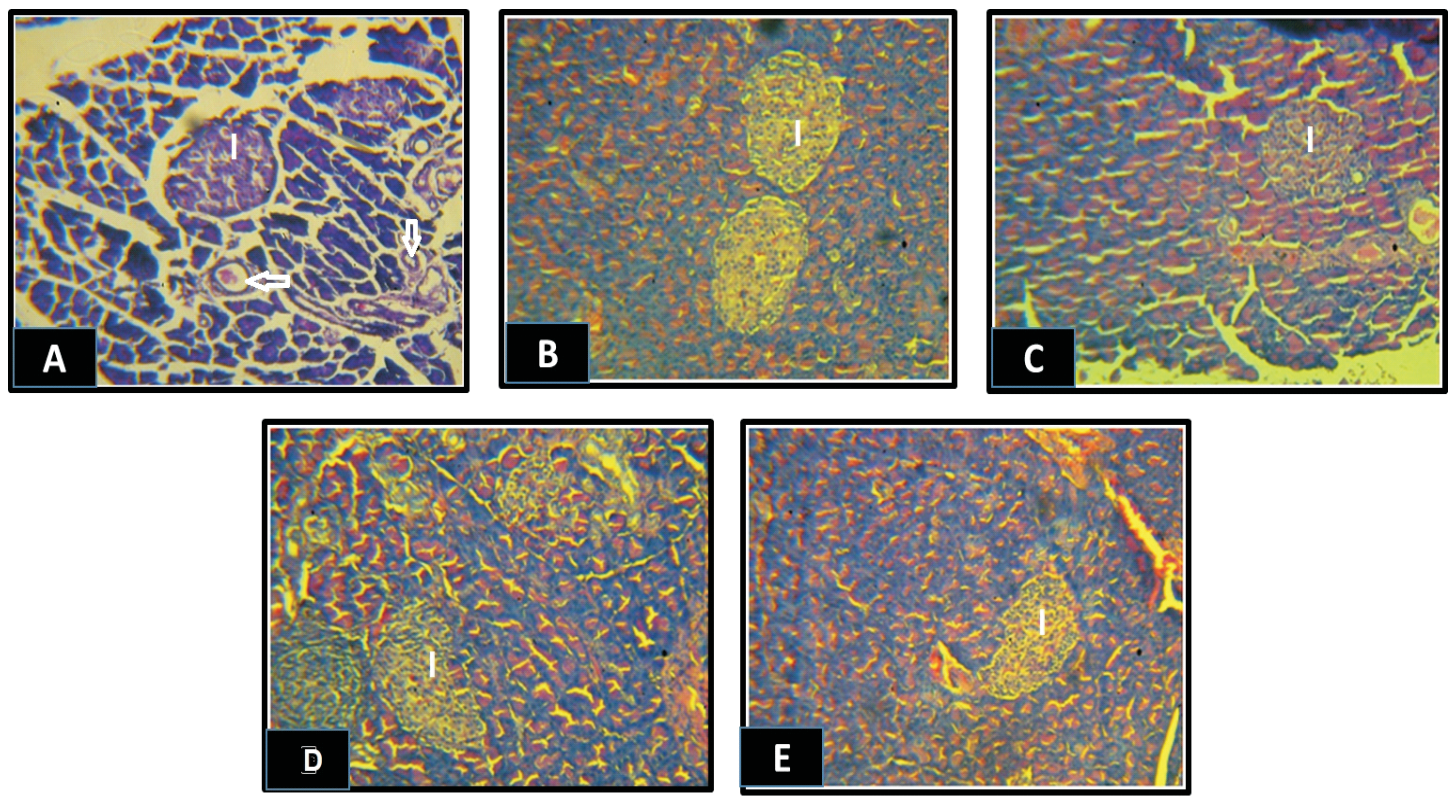

Figure 3: Pancreas of female Wistar rats given normal saline (A: Control), low dose nicotine (B), with low dose nicotine and Moringa extract (C), high dose nicotine (D), and high dose nicotine and Moringa extract (E). The Control group showed apparently normal pancreatic architecture, with well-defined interlobular ducts (arrows) and adequately delineated pancreatic islets of Langerhans (I), while the pancreas of treated rats showed reduced staining intensity. The outline of the pancreatic islets was fairly preserved in figure B; however, distorted outline, cellular degeneration, poorly defined and degenerating islets of Langerhans were observed in other treated groups, especially in groups D and E. H\&E x100. 